\title{
Diagnostic Accuracy of Elastography and Scintigraphic Imaging After Thermal Microwave Ablation of Thyroid Nodules
}

\section{Microwave ablation of thyroid nodules - Mikrowellenablation von Schilddrüsenknoten}

Authors

Affiliations
H. Korkusuz ${ }^{1}$, C. Happel ${ }^{1}$, J. Klebe ${ }^{1}$, H. Ackermann² ${ }^{2}$ F. Grünwald ${ }^{1}$

Department of Nuclear Medicine, Johann Wolfgang Goethe University Hospital, Frankfurt, Germany

Department of Biomathematics, Johann Wolfgang Goethe University Hospital, Frankfurt, Germany

\author{
Key words \\ - head/neck \\ - thyroid \\ - ablation procedures \\ - radionuclide imaging
}

received $\quad 6.8 .2014$

accepted 14.11.2014

Bibliography

Dol http://dx.doi.org/ 10.1055/s-0034-1385827

Published online: 16.1.2015

Fortschr Röntgenstr 2015; 187:

353-359 ๑ Georg Thieme

Verlag KG Stuttgart · New York . ISSN 1438-9029

\section{Correspondence}

Dr. Huedayi Korkusuz Department of Nuclear Medicine, Johann Wolfgang Goethe University Hospital Theodor-Stern-Kai 7

60590 Frankfurt

Germany

Tel.: +49 69/63 01-6783

Fax: +4969/63 01-7143

huedayi.korkusuz@kgu.de

\section{Zusammenfassung \\ $\nabla$}

Ziel: Ziel der Studie ist die Evaluation des diagnostischen Potenzials von Szintigrafie und Elastografie zur Detektion von Gewebsveränderungen in Schilddrüsenknoten nach Mikrowellenablation. Material und Methoden: Fünffunddreißig Patienten mit 39 Schilddrüsenknoten wurden mit Mikrowellenablation unter Ultraschallkontrolle behandelt. Die Elastografie und Szintigrafie wurde vor und nach Mikrowellenablation durchgeführt. Für die Elastografie wurde ein farbcodierter Elastizitätsscore eingeführt (ES). Schilddrüsenknoten hoher Elastizität mit blauer Farbkodierung wurden als ES1 definiert, über ES2 und ES3 mit entsprechend geringerer Elastizität bis zu ES4 für Knoten mit sehr niedriger Elastizität und roter Farbcodierung. Die Szintigrafie erfolgte unter Anwendung von ${ }^{99 m}$ Tc-Pertechnetat zur Darstellung heißer und indifferenter Schilddrüsenknoten, sowie unter Einsatz von ${ }^{99 m}$ Tc-MIBI bei kalten Knoten.

Ergebnisse: Die Elastografie zeigte vor Ablation einen medianen Elastizitätsscore aller Schilddrüsenknoten von ES $2 \pm 0,7$. Durch die Ablation ergab sich eine Erhöhung des Scores (um 1ES $\pm 0,6$ $(p<0,01)$ ). Der mediane ES aller Knoten lag nach Mikrowellenablation bei $3 E S \pm 0,6$. Szintigrafisch zeigte sich eine mediane Reduktion der Aufnahme im abladierten Gewebe um 38,7\% 27,5( $\mathrm{p}<0,01)$. Für die Schilddrüsenknoten, die mit 99mTc-Pertechnetat dargestellt wurden, ergab sich ein medianer Rückgang der Aufnahme von $26,3 \% \pm 16,3$, bei ${ }^{99 m}$ Tc-MIBI eine Reduktion der Aufnahme abladierter Knoten um 54,7\% 29,2 .

Schlussfolgerung: Die szintigrafische Darstellung mit ${ }^{99 m}$ Tc-Pertechnetat und ${ }^{99 m} \mathrm{mc}-\mathrm{MIBI}$ ist eine vielversprechende Methode zur Nachsorge nach Mikrowellenablation und bietet quantifizierbare Ergebnisse. Elastografie kann Gewebsveränderungen nach Ablation detektieren, ist jedoch weniger präzise aufgrund der notwendigen Reduktion der Bildgebung auf einzelne Elastizitätsscores.

\section{Abstract \\ $\nabla$}

Purpose: The aim of this study is to evaluate structural alterations of thyroid tissue after microwave ablation using elastography and scintigraphic imaging to investigate the applicability of these diagnostic methods for follow-up.

Materials and Methods: 35 patients with 39 thyroid nodules were evaluated using elastography and scintigraphic imaging before and after ultrasound-guided microwave ablation. Elastography was analyzed according to color-coded output and results were classified using a fourfold elasticity score (ES). Nodules color-coded blue were classified ES1 for high elasticity through ES2 and ES3 for lower elasticity, and nodules with very low elasticity were color-coded red and classified as ES4. ${ }^{99 \mathrm{~m} T c-p e r t e c h n e t a t e ~ s e r v e d ~ a s ~ a ~ t r a c e r ~ f o r ~}$ scintigraphic imaging of hot and indifferent nodules and ${ }^{99 m}$ Tc-MIBI for cold nodules.

Results: Before microwave ablation, elastography detected a median elasticity score of ES $2 \pm 0.7$, and after ablation the median score was ES 3 \pm 0.6 . Overall, the median score increased by $1 \mathrm{ES}$ $\pm 0.6(p<0.01)$. Scintigraphic imaging detected a median reduction of tracer uptake in ablated tissue of $38.7 \% \pm 27.5(\mathrm{p}<0.01)$. ${ }^{99 m} \mathrm{Tc}$-pertechnetate scans showed a median decrease of tracer uptake of $26.3 \% \pm 16.3$ and ${ }^{99 m}$ Tc-MIBI scans detected uptake reduction of $54.7 \% \pm 29.2$.

Conclusion: Scintigraphic imaging using ${ }^{99 m T c-}$ pertechnetate and ${ }^{99 \mathrm{~m} T c-M I B I}$ provides quantifiable results and is promising as a diagnostic follow-up after microwave ablation. Strain elastography detects decreasing tissue elasticity, but accuracy is limited by the necessary reduction of color-coded output to elasticity scores.

Key points:

- Scintigraphic imaging provides quantifiable information about tissue alterations after microwave ablation. 
Kernaussagen:

- Die Schilddrüsenszintigrafie kann Gewebeveränderungen nach Mikrowellenablation quantifizierbar detektieren.

- Elastografie zeigt geringere diagnostische Präzision als Szintigrafie.

- Mikrowellenablation ist ein vielversprechendes Verfahren zur Behandlung von Schilddrüsenknoten.

- Die Szintigrafie erlaubt Rückschlüsse auf die zelluläre Integrität in Ablationsbereichen nach Mikrowellenablation.
- Elastography provides less precise diagnostic information after ablation than scintigraphy.

- Microwave ablation is a promising technique for the treatment of thyroid nodules.

- Scintigraphic imaging allows the drawing of conclusions about cell integrity in the ablated areas.

Citation Format:

- Korkusuz H, Happel C, Klebe J etal. Diagnostic Accuracy of Elastography and Scintigraphic Imaging After Thermal Microwave Ablation of Thyroid Nodules. Fortschr Röntgenstr 2015; 187: 353-359

\section{Introduction}

$\nabla$

Thyroid nodules can be found in a very high percentage of patients [1]. In some cases remaining completely asymptomatic, thyroid nodules might also cause symptoms such as hoarseness, dyspnea or foreign body sensations. In some circumstances they do not remain benign but have the potential of malignant transformation [2]. Besides surgical intervention and radioiodine therapy, there are several options in treating these thyroid nodules in order to reduce their volume. Particularly in the last decade, some innovations and novelties in the treatment of thyroid nodules were developed. Promising results were described using minimally invasive therapy approaches such as radiofrequency ablation [3] or microwave ablation [4-7] to reduce thyroid nodule volumes.

Microwave ablation is a very recent development in treating benign thyroid nodules, but it has also gained an important role in treating pathologies of other parenchyma. The first encouraging results of microwave ablation treatments have been reported in the therapy of hepatocellular carcinoma [8]. Microwave ablation offers several advantages in comparison to other ablation techniques: shorter ablation time, it is able to generate larger ablation zones and it is less susceptible to heat sink effects [9]. The underlying principle of microwave ablation is the thermal heating of tissue via agitation of water molecules using electromagnetic microwaves [10].

While scintigraphic imaging is well established in the assessment of the consistency of thyroid nodules [11], elastography is a more recent diagnostic tool and its efficacy as a sole diagnostic method for detecting thyroid pathologies and malignancies is controversially discussed [12]. Quasi-static [13] ultrasound elastography is a new technique measuring tissue stiffness by detecting tissue distortion under manual compression [14].

Studies on liver tissue in a porcine model using radiofrequency ablation (RFA) as a thermal ablation method detected that elastographic tests show a decreased tissue elasticity following ablation [15]. Other studies on RFA in in vivo porcine liver tissue showed that elastography is superior to B-mode ultrasound since it is less susceptible to artifacts [16]. In comparison to the results of gross specimen evaluation, elastography slightly underestimates the size of the ablation zone [17].

Evaluating the result of thermal ablation procedures using scintigraphic imaging and elastography as a diagnostic follow-up is a novel approach. There were no studies yet reported on elastography and scintigraphic imaging after microwave ablation of thyroid nodules.

Considering that microwave ablation has an influence on tissue characteristics, these transformations ought to be detected using elastography and scintigraphic imaging as two different imaging methods. The aim of this study was to elucidate observable al- terations of thyroid tissue after microwave ablation via strain elastography and scintigraphic imaging and to evaluate the feasibility of these diagnostics for the follow-up of microwave ablated thyroid nodules.

\section{Materials and Methods \\ $\nabla$}

\section{Patients}

35 patients (18 male, 17 female, age range $29-81$ years) with 39 thyroid nodules were included in this study and underwent microwave ablation.

The inclusion criteria were: (a) symptomatic thyroid nodules or cosmetic concerns, (b) contraindication for surgical intervention or patient's preference, (c) nodules detected as "cold" by scintigraphic imaging. The exclusion criteria were: (a) asymptomatic nodules, (b) retrosternal location and excessive nodule volume, (c) nodules highly suspicious or proven to be malignant, (d) vicinity of critical structures such as blood vessels, nerves, esophagus or trachea.

Written informed consent was obtained from all patients. The local ethics committee approved the study protocol.

\section{Pre-assessment}

All nodules were pre-evaluated using laboratory tests, B-mode ultrasound (Sonix Touch Ultrasound system, Ultrasonix Medical Corporation, Richmond, Canada), elastography, scintigraphic imaging and fine-needle aspiration cytology to exclude patients with malignant thyroid nodules.

Strain elastography was performed using the elastography imaging software of the Sonix Touch Ultrasound system (Ultrasonix Medical Corporation, Richmond, Canada) and a linear transducer. Prior to microwave ablation, all patients underwent elastography. A color-coded ultrasound elastography output was used. Color ranges were then classified as elasticity scores (ES) [18]. Nodules with high elasticity (color-coded as blue) were classified as ES1, predominantly soft nodules with mixed elasticity as ES2, predominantly hard nodules with mixed elasticity as ES3 and nodules with low elasticity as ES4. The elastosongraphic ultrasound system provided a compression feedback chart to control the amount of manual compression in real-time and enabled reproducible conditions.

Scintigraphic imaging was performed using two different types of tracers, ${ }^{99 \mathrm{~m}} \mathrm{Tc}$-pertechnetate and ${ }^{99 \mathrm{~m} T c-M I B I}$. All patients underwent ${ }^{99} \mathrm{~m}$ Tc-pertechnetate imaging prior to microwave ablation and nodules were then classified as "cold" (reduced tracer uptake), "indifferent" (neutral tracer uptake) and "hot" (increased tracer uptake) with respect to the ${ }^{99 \mathrm{~m}} \mathrm{Tc}$-pertechnetate uptake compared to the surrounding thyroid tissue. 
Thyroid nodules classified as cold were subjected to fine-needle aspiration cytology in order to exclude cold nodules of malignant pathology. Additionally, cold nodules then gained scintigraphic $99 \mathrm{mTc}-\mathrm{MIBI}$ imaging prior to and after microwave ablation. ${ }^{99 \mathrm{mTc}-}$ MIBI is expected to detect malignant thyroid nodules with high sensitivity [19]. In thyroid nodules, previously diagnosed as "indifferent" or "hot", ${ }^{99}$ mc-pertechnetate imaging was used for scintigraphic imaging after microwave ablation.

Scintigraphic imaging scans were taken 20 minutes after intravenous injection of a dose of $75 \mathrm{MBq}$ of ${ }^{99} \mathrm{mTc}$-pertechnetate. In cases of scintigraphic imaging using MIBI, the dosage and time were $500 \mathrm{MBq}$ and 10 and 60 minutes, respectively. Scintigraphic images were recorded using a gamma camera (Mediso Ketronic Nucline ${ }^{\circledR}$ $\mathrm{TH} / 22$, Mediso GmbH, Medical Imaging Systems, Münster, Germany; Software InterView XP121) equipped with a LETH collimator. In total, 27 thyroid nodules were classified as "cold"; 11 as "indifferent" and a single nodule in one patient was detected as "hot", according to the pertechnetate scan.

\section{Microwave ablation procedure}

For microwave ablation, patients were placed in a supine position with a hyper-extended neck. Microwave ablation procedures were all performed by the same operator under ultrasound guidance (Sonix Touch Ultrasound system; Ultrasonix Medical Corporation, Richmond, Canada).

The puncture site was anesthetized by injecting Scandicain (1\%) subcutaneously prior to the procedure. If thyroid nodules showed cystic components, fluid was aspirated prior to microwave ablation. The skin was then incised and the probe was positioned under ultrasound guidance using a preferential transisthmic access to spare critical structures [20]. In exceptional cases of adverse conditions, craniocaudal access was chosen as an alternative. If more than one symptomatic nodule was found in one patient, nodules were ablated consecutively during the same procedure.

The microwave ablation system used in the present study (Avecure MWG881, MedWaves Incorporated, San Diego, CA, USA) generates frequencies of $902-928 \mathrm{MHz}$ and maximum temperatures of $140{ }^{\circ} \mathrm{C}$. The ablation time, wattage and temperature were adapted individually for each patient due to ultrasound findings. Probes with different diameters (14 to 16 gauge with respect to nodule size) with an uncooled tip and integrated temperature sensor were used. The temperature was monitored continuously in order to prevent the temperature from reaching over $90^{\circ}$ or under $60^{\circ} \mathrm{C}$. The wattage output was individually adapted from 24 to $32 \mathrm{~W}$.

During the ablation process real-time ultrasound was sustained until the end of microwave ablation to assure accurate positioning of the microwave ablation probe. Frequent communication between the patient and operator enabled constant monitoring of voice changes in order to prevent nerve palsies.

Post-assessment

Elastography was performed immediately after microwave ablation. Laboratory tests were examined 24 hours post procedure. Scintigraphic imaging was performed the day after microwave ablation. B-mode ultrasound examination of the nodule was repeated one day after microwave ablation to detect potential complications.

\section{Statistical analysis}

Elastographic and scintigraphic results were carried out using the "BIAS", software version 10.04 (epsilon Verlag, 1989-2013 Hochheim, Darmstadt, Germany). Wilcoxon's matched pairs test was performed to compare scintigraphic measurements before and after microwave ablation. Elastographic results were tested using Wilcoxon's matched pairs test. Statistical significance was indicated with p-values of less than 0.05. Descriptive statistical analyses are given as median \pm standard deviation.

\section{Results}

\section{$\nabla$}

\section{Elastography}

Before microwave ablation, 3 thyroid nodules were assigned to ES1 by strain elastography, 17 nodules to ES2, 16 nodules to ES3, 3 nodules to ES4 ( $\bullet$ Table 1 ). The median elasticity score prior to ablation procedure was ES $2 \pm 0.7$.

After microwave ablation the median ES was $3 \pm 0.6$. No more thyroid nodules were classified as ES1, 3 nodules were classified as ES2, 17 were classified as ES3 and 19 nodules could be classified as ES4. Overall, 32 of 39 thyroid nodules showed an increased elasticity score by one or two units. The median decrease in elasticity referring to all nodules was ES $1 \pm 0.6(p<0.01)$.

\section{Scintigraphic imaging}

The results of pre and post ablation scintigraphic imaging of the ablated area were evaluated and analyzed. A median decline of $38.7 \% \pm 27.5(p<0.01)$ in tracer uptake was found in ablated thyroid tissue. In ablated cold nodules a median reduction of uptake by $54.7 \% \pm 29.9$ was observed, in indifferent nodules by $31.5 \% \pm 16.2$ and in the single hot nodule tracer uptake reduced by $38.1 \%$ ( Table 1 ).

With respect to the used tracers, ${ }^{99 \mathrm{~m} T c-M I B I}$ scans showed a median reduction of uptake in ablated thyroid nodules of $54.7 \%$ \pm 29.2 and in ${ }^{99} \mathrm{~m}$ Tc-pertechnetate scans the median tracer uptake in the ablated area was reduced by $26.3 \% \pm 16.3$.

\section{Discussion \\ $\nabla$}

Due to the very recent development of microwave ablation as a minimally invasive procedure for reducing the volume of thyroid nodules, studies on the thermal effects on treated tissue are still rather scarce. A study by Zhou et al. [21] compared the effect of microwave ablation on different parenchyma ex vivo in a porcine model and showed that the size of the ablation zone does not vary much between muscle, liver and adipose tissue. There have neither been studies performed on the impact of microwave ablation on thyroid tissue at the molecular level nor on the histopathologic alterations on thyroid parenchyma after microwave ablation, so it can only be presumed that the effects of microwave ablation on thyroid tissue might be comparable to those of other parenchyma.

Scintigraphic imaging is an important diagnostic tool in the characterization of thyroid pathology. Etzel et al. stated in a previous study that scintigraphic imaging could not be replaced by elastography with respect to the accuracy of diagnosing thyroid pathologies [18]. In the past, technical innovations in other diagnostic tools have not been able to displace the importance of scintigraphic imaging in thyroid diagnostics [11].

In the present study two different types of tracers were used, $99 \mathrm{~m}$ Tc-pertechnetate and $99 \mathrm{mTc}-\mathrm{MIBI}$. As a substrate of the sodium iodide symporter [22] in thyroid cells, the tracer ${ }^{99} \mathrm{~m}$ Tc-pertechnetate is taken up into iodine storing cells of the thyroid gland. The scintigraphic findings of the present study show a re- 
Table 1 Diagnostic characteristics of thyroid nodules before and after microwave ablation procedure.

Tab. 1 Diagnostische Kriterien aller evaluierten Schilddrüsenknoten vor und nach der Mikrowellenablation.

\begin{tabular}{|c|c|c|c|c|c|c|}
\hline \multirow[t]{2}{*}{ nodule } & \multirow{2}{*}{$\begin{array}{l}\text { type of nodule (based on } \\
\text { scintigraphic assessment } \\
\text { using } 99 \mathrm{mTC} \text {-pertechnetate) }\end{array}$} & \multicolumn{2}{|c|}{ elastography } & \multicolumn{3}{|c|}{ scintigraphic imaging } \\
\hline & & $\begin{array}{l}\text { elasticity } \\
\text { score prior } \\
\text { to MWA }\end{array}$ & $\begin{array}{l}\text { elasticity score } \\
\text { after MWA }\end{array}$ & $\begin{array}{l}\text { percentage tracer } \\
\text { uptake in ablation } \\
\text { zone prior to } \\
\text { MWA [\%] }\end{array}$ & $\begin{array}{l}\text { percentage tracer } \\
\text { uptake in ablation } \\
\text { zone after } \\
\text { MWA [\%] }\end{array}$ & $\begin{array}{l}\text { percentage } \\
\text { reduction of } \\
\text { tracer uptake in } \\
\text { ablation zone [\%] }\end{array}$ \\
\hline 1 & cold & 2 & 3 & 17.9 & 10.7 & 40.4 \\
\hline 2 & cold & 2 & 3 & 3.2 & 2.8 & 13.4 \\
\hline 3 & indifferent & 2 & 3 & 3.6 & 2.2 & 38.7 \\
\hline 4 & cold & 1 & 2 & 12.1 & 11.2 & 7.5 \\
\hline 5 & hot & 2 & 3 & 41.0 & 25.4 & 38.1 \\
\hline 6 & indifferent & 2 & 3 & 8.7 & 7.1 & 18.7 \\
\hline 7 & cold & 2 & 2 & 12.8 & 7.1 & 44.5 \\
\hline 8 & cold & 3 & 4 & 11.2 & 0.0 & 100.0 \\
\hline 9 & cold & 3 & 3 & 15.3 & 6.9 & 54.7 \\
\hline 10 & cold & 3 & 4 & 23.2 & 6.5 & 71.9 \\
\hline 11 & indifferent & 3 & 4 & 20.8 & 8.1 & 61.4 \\
\hline 12 & indifferent & 3 & 4 & 38.7 & 24.0 & 37.9 \\
\hline 13 & cold & 1 & 3 & 15.5 & 0.0 & 100.0 \\
\hline 14 & cold & 2 & 4 & 9.0 & 3.6 & 59.8 \\
\hline 15 & cold & 4 & 3 & 17.4 & 10.4 & 40.1 \\
\hline 16 & cold & 3 & 4 & 6.0 & 5.5 & 9.6 \\
\hline 17 & indifferent & 3 & 4 & 5.0 & 3.3 & 33.1 \\
\hline 18 & indifferent & 3 & 4 & 7.5 & 3.3 & 55.8 \\
\hline 19 & indifferent & 2 & 3 & 6.1 & 4.2 & 31.5 \\
\hline 20 & cold & 2 & 4 & 7.5 & 6.6 & 12.6 \\
\hline 21 & cold & 3 & 4 & 25.9 & 9.3 & 64.2 \\
\hline 22 & cold & 2 & 3 & 13.2 & 12.3 & 7.0 \\
\hline 23 & cold & 2 & 4 & 10.3 & 9.1 & 11.7 \\
\hline 24 & cold & 2 & 3 & 17.4 & 15.9 & 8.6 \\
\hline 25 & cold & 2 & 3 & 30.7 & 5.5 & 82.2 \\
\hline 26 & indifferent & 2 & 3 & 4.9 & 4.7 & 3.5 \\
\hline 27 & indifferent & 3 & 4 & 5.8 & 4.6 & 21.1 \\
\hline 28 & cold & 1 & 2 & 32.1 & 9.2 & 71.4 \\
\hline 29 & cold & 2 & 3 & 35.4 & 14.4 & 59.3 \\
\hline 30 & cold & 3 & 4 & 7.0 & 5.0 & 29.5 \\
\hline 31 & cold & 2 & 3 & 15.0 & 9.7 & 35.2 \\
\hline 32 & indifferent & 4 & 4 & 9.3 & 7.5 & 19.3 \\
\hline 33 & indifferent & 3 & 3 & 19.8 & 15.7 & 20.6 \\
\hline 34 & cold & 3 & 4 & 7.5 & 2.9 & 61.4 \\
\hline 35 & cold & 3 & 3 & 18.3 & 5.6 & 69.3 \\
\hline 36 & cold & 3 & 4 & 18.3 & 1.9 & 89.5 \\
\hline 37 & cold & 3 & 4 & 12.8 & 1.2 & 90.3 \\
\hline 38 & cold & 4 & 4 & 45.6 & 19.3 & 57.6 \\
\hline 39 & cold & 2 & 4 & 13.8 & 11.4 & 17.4 \\
\hline
\end{tabular}

duction of tracer uptake in thyroid tissue volume after microwave ablation. This can be explained by the effect of microwave ablation as a thermal treatment. Due to thermal heating of the ablated tissue, iodine storing and hormone-producing thyroid tissue is destroyed. In the case of ${ }^{99} \mathrm{~m}$ Tc-pertechnetate, "indifferent" or "hot" thyroid nodules, comprising intact iodine storing cells, are destroyed and subsequently scintigraphic imaging shows reduced tracer uptake in ablated tissue. Comparable results have been described in a number of cases by a study by Baek et al. [23] after radiofrequency ablation.

Since "cold nodules" do not show any uptake of $99 \mathrm{mTc}$-pertechnetate, ${ }^{99} \mathrm{~m}$ Tc-MIBI has to be used as an alternative tracer to provide a comparison of uptake in "cold" nodules prior to and after microwave ablation. Previous studies have demonstrated the high potential of MIBI in detecting malignant thyroid nodules with high sensitivity, especially when combined with fine-needle aspiration cytology [24]. However, the uptake of $99 \mathrm{mTc}$-MIBI is not only present in nodules of suspected malignancy, but also in benign cold nodules. The diagnostic interpretation of malignant potential mainly refers to the observable time periods of ${ }^{99} \mathrm{mTc}-\mathrm{MIBI}$ uptake, retention and washout [25]. Its uptake and accumulation are assumed to be associated with the presence of intact mitochondria [26]. The accumulation of ${ }^{99} \mathrm{mTc}$ TMIBI is dependent on specific mitochondrial membrane potentials; necrosis destroys these mitochondrial membrane potentials and therefore reduces accumulation [27]. Microwave ablation creates such necrotic tissue in the ablated areas. This explains why ${ }^{99 \mathrm{~m} T c-M I B I}$ uptake is reduced after microwave ablation ( $\bullet$ Fig. 1 ), giving rise to a quantifiable measurement even in cold nodules after treatment. 

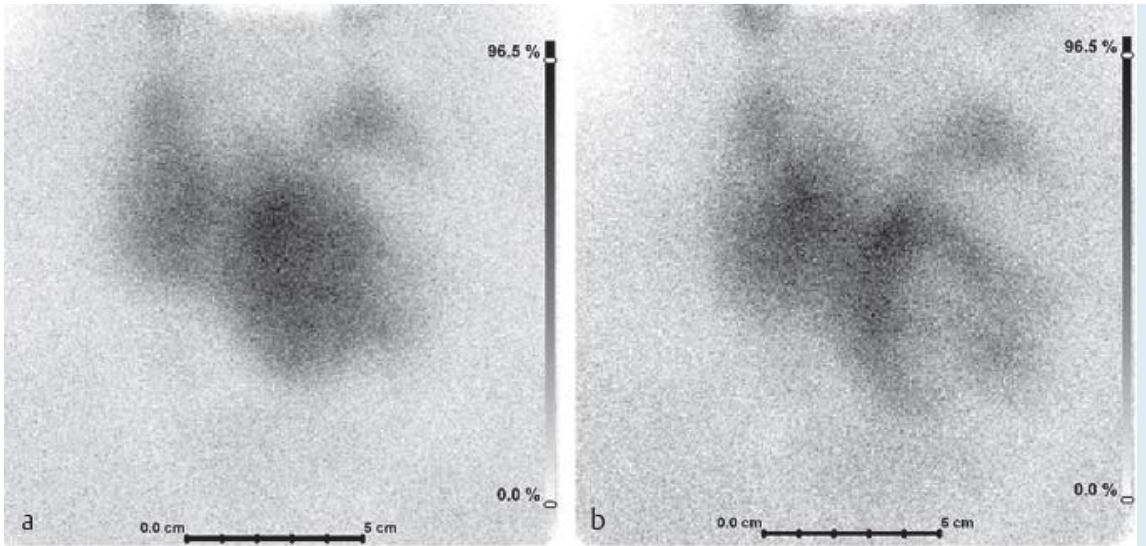

Fig. 1 a Example of scintigraphic imaging using 99m-Technetium-MIBI prior to microwave ablation. The thyroid nodule is located at the caudal part of the left thyroid lobe. b Scintigraphic imaging of the same nodule after microwave ablation. The tracer uptake is decreased after microwave ablation in the ablated thyroid nodule.

Abb. 1 a Szintigrafische Bildgebung eines Schilddrüsenknotens (kaudaler Anteil des linken Schilddrüsenlappens) vor der Mikrowellenablation unter Verwendung von ${ }^{99 m-T e c h n e t i u m-M I B I . ~ b ~ S z i n t i g r a-~}$ fie desselben Knoten nach erfolgter Mikrowellenablation. Die Anreicherung des Tracers im abladierten Schilddrüsenknoten ist im Vergleich zu vorher deutlich reduziert.
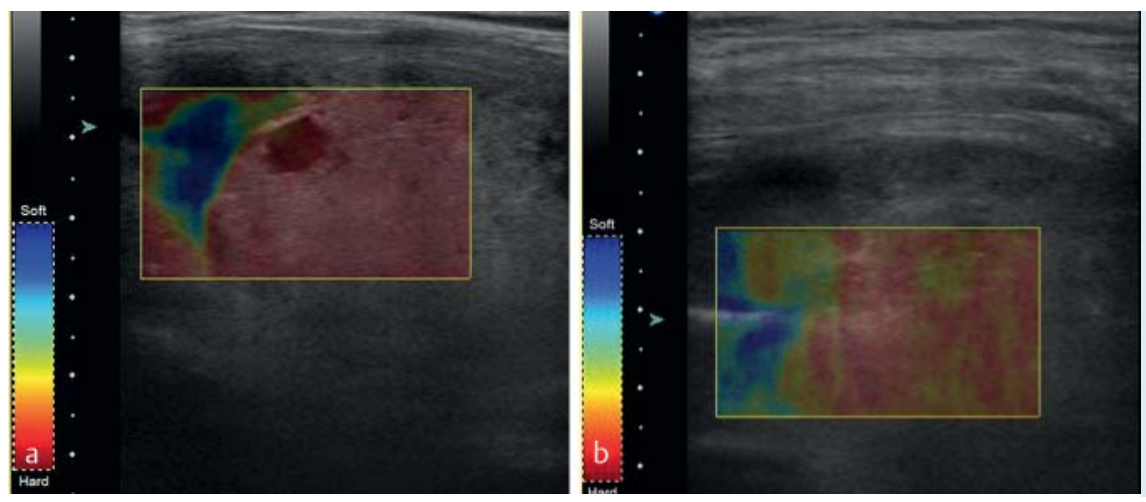

Fig. 2 a Elastographic imaging of a thyroid nodule before microwave ablation, showing a hypoechoic cystic component. $\mathbf{b}$ Imaging of the same nodule after aspiration of fluid content and microwave ablation.

Abb. 2 a Beispiel für eine elastografische Darstellung eines Schilddrüsenknotens mit hypoechogenem zystischen Anteil vor Mikrowellenablation.

b Elastografie des Schilddrüsenknotens nach Punktion des flüssigen Anteils und nach erfolgter Mikrowellenablation.

Since scintigraphic imaging can provide high resolution imaging, the comparison of before and after scans can provide numeric analysis and a percentage reduction of tracer uptake in tissue. Hence, it allows the drawing of conclusions on the volume of necrotic tissue evoked by microwave ablation.

Elastography is a newly developed technique featured by many ultrasound systems and was appraised enthusiastically as a new method for the diagnostic evaluation of thyroid nodules. However, does the method achieve the required accuracy?

Van Vledder et al. [16] described elastography as a reasonable monitoring method after radiofrequency ablation on hepatic tissue, assuming that the thermal ablation procedure will lead to elevated tissue stiffness due to protein denaturation and dehydration. A study by DeWall et al. [28] also suggests evaporation of free water as an explanation for the observed reduction of tissue elasticity. Another study by Varghese et al. [29] compared the results of histopathology and elastography in size and found a high correlation. Despite these convincing correlations, in some cases elastography seems to slightly underestimate the size of the ablation zone [17], which increases the risk of incomplete ablation and subsequent recurrence. Nevertheless, none of the previously mentioned studies used microwave ablation but rather other ablation methods.

Strain elastography as a color-coded imaging method provides hardly quantifiable results. The necessary reduction of results to a single elasticity score for each nodule leads to imprecise diagnostics. In most of our studied cases (32 nodules out of 39 nodules), the elasticity score was elevated by one or two units in the score after microwave ablation, suggesting an increase in tissue stiffness in the ablated region ( $\bullet$ Fig. 2 ). Six nodules showed no difference in elasticity score after microwave ablation. In con- trast, scintigraphic imaging detected a clear reduction of tracer uptake in the ablated zone also of these six nodules, which leads to the assumption that scintigraphic imaging provides superior sensitivity in detecting alterations of thyroid tissue following microwave ablation. In the present study elastography was performed using a strain elastography system based on manual compression. Although a real-time feedback chart allowed constant monitoring of the intensity of the applied manual compression, minor variations in force application are difficult to recognize but might negatively affect the results in correct imaging. Improvements in elastographic imaging, particularly with respect to unbiased and reliable quantitative measurements, are of utmost importance. Although shear wave elastography and other novelties might provide a promising perspective, at present the commonly applied elastography systems do not seem to be technically mature and reliable enough to justify the use of elastography as a sole diagnostic method in detecting thyroid lesions of malignancy and should therefore be considered with suspicion [30].

It remains to be seen whether any future technical developments will make elastography more applicable and the extent to which its reliability and diagnostic significance might develop.

Therefore, it can be suggested that scintigraphic imaging, which provides a more differentiated diagnostic tool for the tissue alteration following microwave ablation, is currently the method of choice.

In the present study functional imaging was assessed to detect early-stage postablative effects. These effects are most likely to occur on molecular and not structural levels. Tracer uptake is based on molecular processes, as described by Kogai et al. [22] and Arbab et al. [26], and may display necrosis even before struc- 
tural alterations happen. Therefore, it makes even early-stage evaluation feasible. Elastography and other ultrasound-based technologies, such as conventional B-mode sonography, may not reflect these molecular-based alterations but rather detect structural alterations of ablated tissue. Correa-Gallego et al. [31] and Pareek et al. [32] showed that ultrasound and elastography, as a technique based on ultrasound, tend to underestimate the size of ablated areas. Zhou et al. [33] found that B-mode ultrasound is not capable of reflecting the proper shape of thermal lesions.

To verify that the observed size of ablation in functional imaging correlates with the real necrotic area, histopathology and gross specimen examination of the thyroid parenchyma would be needed. The present study is limited by a small sample size and short follow-up times. Future studies including longer follow-up periods will show the extent to which treated tissue develops over time after microwave ablation.

\section{Conclusion}

In order to achieve the most accurate diagnostic results for follow-up diagnostics after microwave ablation, scintigraphic imaging is a promising and superior diagnostic method, as it provides quantifiable results indicated by the reduction of tracer uptake in thyroid tissue. Further research will be necessary to decide whether scintigraphic imaging might be used as a sole method for follow-up or should be combined with other diagnostic indicators. In this study it was observed that strain elastography using color-coded imaging is able to detect an increase in tissue stiffness in ablated thyroid tissue. However, the given technical abilities limit its utility in supplying reliable and quantifiable results at present.

In contrast to the measurement of tissue stiffness in elastography, which might be altered for very different reasons, scintigraphic diagnostics are based on the evaluation of cell integrity expressed in terms of tracer uptake in iodine storing cells or in cells providing intact mitochondrial membrane potentials.

\section{Clinical relevance}

- Scintigraphic imaging is a promising diagnostic option for the evaluation of treatment success.

- Strain elastography detects tissue alterations but its accuracy is limited.

- Microwave ablation induces a reduction of tracer uptake in ablated thyroid nodules.

- Tissue elasticity is decreased in ablated thyroid nodules after microwave ablation.

\section{References}

1 Reiners C, Wegscheider K, Schicha $\mathrm{H}$ et al. Prevalence of thyroid disorders in the working population of Germany: ultrasonography screening in 96278 unselected employees. Thyroid 2004; 14: 926 -932

2 Popoveniuc G, Jonklaas J. Thyroid Nodules. Med Clin North Am 2012; 96: $329-349$

3 Baek JH, Kim YS, Lee D et al. Benign predominantly solid thyroid nodules: prospective study of efficacy of sonographically guided radiofrequency ablation versus control condition. Am J Roentgenol 2010; 194: $1137-1142$
4 Yue W, Wang S, Wang B et al. Ultrasound guided percutaneous microwave ablation of benign thyroid nodules: safety and imaging follow-up in 222 patients. Eur J Radiol 2013; 82: e11 - e16

5 Feng $B$, Liang $P$, Cheng $Z$ et al. Ultrasound-guided percutaneous microwave ablation of benign thyroid nodules: experimental and clinical studies. Eur J Endocrinol 2012; 166: 1031 - 1037

6 Korkusuz H, Happel C, Grünwald F. Ultrasound guided percutaneous microwave ablation of hypofunctional thyroid nodules- evaluation by scintigraphic 99mTc-MIBI imaging. Nuklearmedizin 2013; 52: N68

7 Korkusuz H, Korkusuz Y, Happel C et al. Mikrowellenablation (MWA) in Kombination mit der Radiojodtherapie (RIT) bei der Behandlung von Schilddrüsenknoten. Nuklearmedizin 2013; 53: A89

8 Liang $P$, Wang $Y, Y u X$ et al. Malignant liver tumors: treatment with percutaneous microwave ablation-complications among cohort of 1136 patients. Radiology 2009; 251: 933 -940

9 Lubner MG, Brace CL, Hinshaw JL et al. Microwave tumor ablation: mechanism of action, clinical results, and devices. J Vasc Interv Radiol 2010; 21: $192-203$

10 Simon CJ, Dupuy DE, Mayo-Smith WW. Microwave ablation: principles and applications. Radiographics 2005; 25 (Suppl 1): S69-S83

11 Meller J, Becker W. The continuing importance of thyroid scintigraphy in the era of high-resolution ultrasound. Eur J Nucl Med Mol Imaging 2002, (Suppl 2): S425-S438

12 Ünlütürk U, Erdogan MF, Demir Ö et al. Ultrasound elastography is not superior to grayscale ultrasound in predicting malignancy in thyroid nodules. Thyroid 2012; 22: 1031 - 1038

13 Varghese T. Quasi-Static Ultrasound Elastography. Ultrasound Clin 2009; 4: 323-338

14 Azizi G, Keller J, Lewis M et al. Performance of elastography for the evaluation of thyroid nodules: a prospective study. Thyroid 2013; 23 : $734-740$

15 Varghese T, Zagzebski JA, Lee FT Jr. Elastographic imaging of thermal lesions in the liver in vivo following radiofrequency ablation: preliminary results. Ultrasound in Med. \& Biol 2002; 28: 1467-1473

16 van Vledder MG, Boctor EM, Assumpcao LR et al. Intra-operative ultrasound elasticity imaging for monitoring of hepatic tumour thermal ablation. HPB 2010; $12: 717-723$

17 Wiggermann P, Jung EM, Glöckner S et al. Real-time elastography of hepatic thermal lesions in vitro: histopathological correlation. Ultraschall in Med 2012; 33: 170-174

18 Etzel M, Happel C, von Müller F et al. Palpation and elastography of thyroid nodules in comparison. Nuklearmedizin 2013; 52: 97-100

19 Giovanella L, Suriano S, Maffioli M et al. 99mTc-sestamibi scanning in thyroid nodules with nondiagnostic cytology. Head Neck 2010; 32: 607-611

$20 \mathrm{Ha} \mathrm{EJ}$, BaekJH, Lee JH. The efficacy and complications of radiofrequency ablation of thyroid nodules. Curr Opin Endocrinol Diabetes Obes 2011; 18: $310-314$

21 Zhou W, Liang M, Pan $\mathrm{H}$ et al. Comparison of ablation zones among different tissues using 2450-MHz cooled-shaft microwave antenna: results in ex vivo porcine models. PLOS ONE 2013; 8: e71873

22 Kogai T, Brent GA. The sodium iodide symporter (NIS): regulation and approaches to targeting for cancer therapeutics. Pharmacol Ther 2012; 135: $355-370$

23 Baek JH, Moon WJ, Kim YS et al. Radiofrequency ablation for the treatment of autonomously functioning thyroid nodules. World J Surg 2009; 33: 1971 - 1977

24 Sathekge MM, Mageza RB, Muthuphei MN et al. Evaluation of thyroid nodules with Technetium-99m MIBI and Technetium-99m pertechnetate. Head Neck 2001; 23: $305-310$

25 Watanabe T, Monzen H, Hara $M$ et al. Pharmacokinetic model of myocradial 99mTc-sestamibi washout. Ann Nucl Med 2013; 27: 279-284

26 Arbab AS, Koizumi K, Toyama $K$ et al. Technetium-99m-Tetrofosmin, Technetium-99m-MIBI and Thallium-201 uptake in rat myocardial cells. J Nucl Med 1998; 39: 266-271

27 Piga M, Cocco MC, Serra A et al. The usefulness of 99mTc-sestaMIBI thyroid scan in the differential diagnosis and managemnet of amiodarone-induced thyrotoxicosis. Eur J Endocrinol 2008; 159: 423-429

28 De Wall RJ, Varghese T, Brace CL. Quantifying local stiffness variations in radiofrequency ablations with dynamic indentation. IEEE Trans Biomed Eng 2012; 59: 728 - 735

29 Varghese T, Techavipoo U, Liu $W$ et al. Elastographic measurement of the area and volume of thermal lesions resulting from radiofrequency ablation: pathologic correlation. Am J Roentgenol 2003; 181: 701 - 707 
30 Carneiro-Pla D. Ultrasound elastography in the evaluation of thyroid nodules for thyroid cancer. Curr Opin Oncol 2013; 25: 1 -5

31 Correa-Gallego C, Karkar AM, Monette S et al. Intraoperative ultrasound and tissue elastography measurements do not predict the size of hepatic microwave ablations. Acad Radiol 2014; 21: $72-78$
32 Pareek G, Wilkinson ER, Bharat S et al. Elastographic measurements of in-vivo radiofrequency ablation lesions of the kidney.J Endourol 2006; 20: $959-964$

33 Zhou Z, Sheng $L, W u$ S et al. Ultrasonic evaluation of micowave-induced thermal lesions based on wavelet analysis of mean scatterer spacing. Ultrasonics 2013; 53: $1325-1331$ 